\title{
Diário Trabalhista e Democracia Racial Negra dos Anos 1940*
}

\author{
Antonio Sérgio Alfredo Guimarães \\ Márcio Macedo
}

\begin{abstract}
epois da campanha abolicionista e da proclamação da República, a mobilização política da população negra brasileira arrefeceu significativamente. O primeiro movimento político negro no período republicano de caráter nacional ocorreu apenas nos anos 1930, com a criação da Frente Negra Brasileira - FNB em São Paulo, que chegou a ter sucursais em vários outros Estados ${ }^{1}$. A agitação e a arregimentação política dos negros eram feitas em torno de idéias e atitudes algumas vezes contraditórias. De modo geral, no entanto, prevaleciam aqueles que enfatizavam a origem mestiça e mulata do povo brasileiro, repudiavam os costumes africanos sobreviventes e pregavam a necessidade de educar as massas negras para livrá-las do preconceito e da ignorância; ainda que houvesse quem, na imprensa negra da época, reafirmasse a raça e a importância da herança cultural africana.
\end{abstract}

Negar que existisse preconceito de raça no Brasil, contudo, era algo que perpassava todos os discursos. Não equivalia, entretanto, como pode parecer à primeira vista, a desconhecer o preconceito de cor que

\footnotetext{
* O levantamento dos números do Diário Trabalhista, que serve de base para este artigo, foi feito com recursos da Fundação de Amparo à Pesquisa do Estado de São Paulo FAPESP e do Programa de Pesquisa, Ensino e Extensão em Relações Étnicas e Raciais do Departamento de Sociologia da Universidade de São Paulo - USP. Este material foi primeiramente analisado por Márcio Macedo (2006), no capítulo 3 de sua dissertação de mestrado.
}

DADOS - Revista de Ciências Sociais, Rio de Janeiro, Vol. 51, n-1, 2008, pp. 143 a 182. 
atormentava os afro-brasileiros. Ao contrário, este é afirmado enfaticamente por todos como sendo praticado indistintamente por brancos e negros. A argumentação já aparece em Luiz Gama (1989) que, como sabemos, reiterava o preconceito de cor dos mulatos "esfolados", que se passavam por brancos. O cerne da argumentação é que os brancos não nutriam ódio aos negros, e os mulatos e mestiços claros expressavam mais freqüentemente preconceito em relação aos pretos. Não seria, pois, um problema de preconceito de raça, como nos Estados Unidos, mas de cor.

O que acontece no período do pós-guerra (1945-1964), com o fim do Estado Novo e a redemocratização do país? Como se reorganiza a identidade cultural e política negra no período democrático, em que se forjou o discurso nacional da democracia racial? (Guimarães, 2005).

A partir de 1944, os intelectuais negros que militaram ou estiveram próximos da FNB voltam a se organizar, mobilizando-se com o objetivo de influenciar a redação da nova Constituição. A mobilização espraia-se agora entre Rio de Janeiro e São Paulo, e não mais de forma focada em São Paulo, como antes do Estado Novo. Em 1944, é fundado, no Distrito Federal, por Abdias do Nascimento e um grupo de amigos, o Teatro Experimental do Negro - TEN ${ }^{2}$. Ainda no Rio de Janeiro, em março de 1945, com o apoio da União Nacional dos Estudantes - UNE, é fundado, pelo mesmo grupo, o Comitê Democrático Afro-Brasileiro, cujo principal objetivo era lutar pela anistia dos presos políticos do Estado Novo. Em novembro de 1945, ocorre em São Paulo a Convenção Nacional do Negro, reunindo em sua maioria ativistas negros da capital paulista e do Distrito Federal ${ }^{3}$. Posteriormente, haveria um outro encontro no Rio de Janeiro, em maio de 1946.

O objetivo da Convenção era lançar as bases para a atuação do novo ativismo negro. Essas bases estão expostas no Manifesto à Nação Brasileira, documento que sumariava as reivindicações dos ativistas presentes e as colocava como propostas a serem debatidas na Assembléia Nacional Constituinte. Os nomes que assinam o manifesto nos fornecem uma idéia da rede que havia sido formada pelo fundador do TEN e que seria fundamental para a sua ação nos anos seguintes ${ }^{4}$.

Neste artigo, nosso esforço é acompanhar em detalhes a formação desse novo caminho de afirmação da especificidade cultural e política dos negros. Nossa estratégia é analisar os textos publicados em $1946 \mathrm{em}$ uma coluna do Diário Trabalhista, do Rio de Janeiro, intitulada "Proble- 
mas e Aspirações do Negro Brasileiro", sob a direção de Abdias do Nascimento. Revistas e jornais como Senzala (1946) e A Alvorada (1936), em São Paulo, e Quilombo (1948-1950), no Rio de Janeiro, entre outros, são também fontes preciosas. Nosso foco, no entanto, nesse momento formador é particularmente ilustrativo do modo como, por exemplo, as bandeiras da FNB (sobretudo a "segunda abolição") serão fundidas com as emergentes ideologias da negritude e da democracia racial, poucos anos depois celebradas pelos dois intelectuais negros mais proeminentes do TEN: o sociólogo Guerreiro Ramos (1915-1982) e o teatrólogo e jornalista Abdias do Nascimento (1914-_). Comecemos por esclarecer o que foi o Diário Trabalhista.

\section{O DIÁRIO TRABALHISTA}

No dia 15 janeiro de 1946, começa a circular, no Rio de Janeiro, o periódico Diário Trabalhista, de propriedade de Eurico de Oliveira ${ }^{5}$, Antonio Vieira de Melo, Mauro Renault Leite (genro do então presidente Eurico Gaspar Dutra) e José Pedroso Teixeira da Silva. Os dois primeiros eram responsáveis pelo funcionamento do jornal, enquanto os últimos eram acionários majoritários. De acordo com Ferreira (2001:185-186), a despeito de exibir

[...] uma orientação política de caráter trabalhista, o jornal visava, na verdade, garantir respaldo popular para o governo Dutra, com quem possuía ligações. Embora Eurico de Oliveira tivesse realmente compromissos com o trabalhismo, chegando a candidatar-se a deputado pelo Partido Trabalhista Brasileiro - PTB, em 1950, o jornal teria, no fundo, restrições às posições petebistas, preocupando-se basicamente em defender o governo.

O fim do mandato de Dutra, em 1950, foi acompanhado das saídas de Leite e Silva do jornal, e o controle acionário passou para Pedro Moacir Barbosa, de modo que, "daí em diante, a linha política do jornal tornou-se mais definida, caracterizando-se por posições abertamente trabalhistas e comprometidas com o governo de Getúlio Vargas" (ibidem). O periódico funcionou até 1961, quando fechou por dificuldades financeiras.

Abdias do Nascimento trabalhou no Diário Trabalhista como repórter entre 1946 e 1948. Na data de lançamento do jornal, estreou uma coluna voltada para a população afro-brasileira, intitulada "Problemas e Aspirações do Negro Brasileiro", na qual anunciava a realização de 
uma enquete sobre a existência ou não de um problema do negro e do preconceito racial ou de cor no Brasil. É possível que nem todos os textos fossem de autoria de Nascimento, que, nessa tarefa, foi auxiliado por Sebastião Rodrigues Alves, Ironides Rodrigues e Aguinaldo Camargo.

\section{O Que Pensavam os Redatores da Coluna}

Aguinaldo Camargo é apresentado ao público do Diário Trabalhista como "advogado, agrônomo e grande ator, além de filósofo e sociólogo" (Diário Trabalhista, 17/2/1946, p. 4). Estaria escrevendo um livro sobre "o problema do negro no Brasil". De fato, porém, como atesta uma das frases da apresentação, exercia o ofício de comissário de polícia no quarto distrito do Rio de Janeiro ${ }^{6}$. Como quase todos os envolvidos na mobilização negra desse período (1944-1947), situava-se em uma posição intermediária da estrutura ocupacional brasileira, de pouco prestígio, especialmente na burocracia estatal; posição estável, mas de pouca remuneração e poder. Alguns, como ele, já tinham um diploma universitário, outros eram estudantes universitários ou haviam completado apenas o curso médio. Embora não fossem desprovidos de grandes aspirações intelectuais e artísticas, nenhum deles desfrutava de reconhecimento intelectual, como deixa claro o modo como Camargo é apresentado ao grande público. A busca de reconhecimento era, certamente, o traço mais marcante dessa geração.

Camargo era simples e reafirmava, sem grande rebuscamento, o principal para o ativismo negro desse momento: havia um preconceito racial no Brasil que não podia ser reduzido a um preconceito de classe:

Já disse atrás que existe o preconceito de cor no Brasil, porém a posição social é que tende a fazer a "classificação étnica" do indivíduo, mais que os característicos somáticos. O negro, mais que qualquer outra classe social, sofre todos os horrores do capitalismo internacional, e seu problema, apesar desse profundo lastro econômico, não se confunde "in totum" com o problema do proletariado brasileiro, cuja solução depende apenas de política governamental (ibidem).

Interessante que são as ciências sociais que legitimam o novo discurso ativista negro, ao contrário da biologia de antes da guerra. Assim, por exemplo, Camargo parece ecoar o culturalismo de Arthur Ramos (1903-1949) ao dizer que "todas as raças são iguais entre si, respeitando-se o momento cultural de suas evoluções através do espaço e do 
tempo" (ibidem). Para ele, aparentemente, o povo brasileiro é majoritariamente mestiço, sendo os negros (pretos) uma minoria.

Ironides Rodrigues é apresentado como estudante de direito. Sua preocupação básica era afirmar o valor intelectual e artístico dos negros, assim como estabelecer em bases científicas a existência de cultura na África. Leitor do francês, Ironides será um dos principais responsáveis pela divulgação no meio negro brasileiro do pensamento da negritude francesa, assim como dos escritores da Harlem Renaissance. Já em 1946, apoiando-se na autoridade de Frobenius (que provavelmente conheceu por meio da leitura de Arthur Ramos), afirmava a existência de civilizações africanas, refutando nominalmente a opinião de Sílvio Romero.

Sempre preocupado em contrapor-se àqueles que julgavam os negros intelectualmente inferiores, é farto e generoso ao citar os intelectuais afro-brasileiros de sua geração:

Raimundo Souza Dantas, no romance; Fernando Góis, contista e crítico literário; Aguinaldo Camargo, sociólogo e ensaísta; Abdias do Nascimento, romancista, faz ainda estudos psicológicos sobre os negros; Lino Guedes, na poesia; Vicente Lima, no folclore e mocambos pernambucanos; Solano Trindade, na sua poética impressionante (Diário Trabalhista, 20/1/1946, p. 5).

Ironides mostrava-se cético em relação ao alinhamento político dos negros, preferindo construir um movimento puramente cultural: “É preciso que os líderes conduzam o povo negro do Brasil pelo caminho certo de sua valorização, não permitindo que exploradores o levem à política partidária que somente interessa aos brancos gananciosos de poder" (ibidem).

Sebastião Rodrigues Alves foi fundador, juntamente com Aguinaldo Camargo e Abdias do Nascimento, no Rio de Janeiro, em março de 1945, do TEN e do Comitê Democrático Afro-Brasileiro. Velho amigo de Abdias, serviu com ele o Exército brasileiro e com ele foi também condenado à prisão, à revelia, por envolvimento em uma briga de rua (Macedo, 2006). Em 1946, Sebastião era presidente da Cruzada Afro-Brasileira de Alfabetização. Escreveu pouco, portanto. O que conhecemos de seu pensamento restringe-se a suas declarações à coluna, nas quais ressalta que a redenção do povo negro virá pela educação: 
O essencial no momento é uma atitude desassombrada dos homens de boa fé e esclarecidos no que se refere à educação do povo. Educar o branco para receber o negro no seu convívio social, livre do medíocre preconceito, educar o negro para participar em todos os setores da vida sem o prejuízo do complexo de inferioridade que é uma herança da senzala e do preconceito (Diário Trabalhista, 23/1/1946, p. 5).

De todos os redatores da coluna, Abdias do Nascimento é o mais refinado politicamente. Seu pensamento, em 1946, refletia o diagnóstico do problema do negro, corrente entre as lideranças, como veremos a seguir, e que seria retomado anos mais tarde por Florestan Fernandes (1965): a abolição, do modo como foi feita no Brasil, jogou de uma hora para outra a população negra em um mercado de trabalho no qual não tinha habilidades para competir:

\begin{abstract}
A base puramente romântica da campanha abolicionista, a ausência de estudos sociológicos objetivos em torno da situação e do futuro da raça e do povo brasileiro permitiram que os africanos e seus descendentes fossem libertos do jugo escravocrata e se vissem de uma hora para outra sem casa, sem comida, e sem trabalho. Já a ninguém mais interessava o braço do negro, quando operários mais capazes aportavam em nosso mercado, escorraçados pela grave crise européia, provocada pelo surto industrial nascido após a descoberta da máquina a vapor (Diário Trabalhista, 23/1/1946, p. 5).
\end{abstract}

Também já se encontra nos escritos jornalísticos de Abdias desses anos a origem do que Florestan batizaria mais tarde, citando a frase de um ativista anônimo, de "preconceito de não ter preconceito":

Causa direta do preceito jurídico de que todos os brasileiros são iguais perante a lei criou-se também uma mentalidade preocupada em negar qualquer preconceito de côr no Brasil, enquanto que [sic] os negros, com poucas oportunidades de elevar seu "standard" de vida por causa da atmosfera de desprestígio em que se viu cercado, refugiou-se nos morros e deles fez seu "habitat" carregando às costas o terrível ônus do analfabetismo, da subalimentação, da tuberculose e do atraso em todos os sentidos (ibidem, ênfases no original).

Para Abdias, a reparação dos erros da República viria apenas com a segunda Abolição, tema caro aos militantes da FNB, para quem a República fora madrasta para com os negros ${ }^{7}$ : 


\begin{abstract}
A República surgiu, e ao invés de estabelecer um plano de amparo e readaptação social da gente negra, o que se visou foi procurar apagar a "mancha" da escravidão na história pátria, chegando ao extremo de cometer erros irresgatáveis como aquele do grande e admirável Rui Barbosa, que na qualidade de ministro da Fazenda, mandou queimar todo o arquivo referente à escravidão. Por causa dessa medida, ainda não pudemos e nem poderemos nunca saber ao certo quantos negros entraram no Brasil, nem as nações de origem daqueles que tão fundamente iriam influir na estruturação espiritual e material da pátria em formação (ibidem).
\end{abstract}

A preocupação de Abdias com a origem dos povos negros denuncia não apenas a influência que Arthur Ramos e a antropologia culturalista já exerciam sobre ele, mas certamente também a influência da négritude francesa, que lhe chegava através de artistas e intelectuais próxi$\operatorname{mos}^{8}$.

O texto de lançamento da coluna, provavelmente escrito e revisto pelos quatro redatores, intitulava-se "Os Negros Brasileiros Lutam por suas Reivindicações" e começava assim: "No Brasil não existem preconceitos de raça; quando muito, recalcitram algumas restrições individuais, vencidas, entretanto, e superadas pela inteligência de homens de côr quando eles, como freqüentes vezes ocorre, constituem intelectos privilegiados" (Diário Trabalhista, 15/1/1946, p. 5).

Passam em seguida a referir-se aos Estados Unidos, onde haveria preconceito de raça, mas os negros foram capazes de construir uma civilização negra paralela e tão pujante quanto a branca. O argumento, ao que parece, serve para estabelecer como verdade a capacidade intelectual dos negros.

No Brasil, prosseguem os colunistas, não existe um problema do negro, mas um problema nacional de pobreza e de falta de educação, que atinge brancos e negros igualmente. Aqui, o "preto seria ainda mais preconceituoso que o branco" (ibidem).

O restante do texto é dedicado a expor os pontos programáticos tirados da Convenção Nacional do Negro, já citados, em que há ao menos três reivindicações que parecem pressupor um "problema do negro" no Brasil: 1) o preconceito de cor deve ser declarado um crime de lesa-pátria;2) deve também ser perseguido criminalmente; $\mathrm{e}$ ) os negros devem ser pensionistas no sistema educacional privado do país quan- 
do não houver vagas em escolas públicas. Essas reivindicações são apresentadas como universalistas, mesmo a última, que, na visão dos redatores, não parece comprometer o diagnóstico anterior de que não há um problema do negro no Brasil. Ou seja, trata-se, na visão deles, de um problema da massa da população brasileira, ela mesma mestiça, preconceituosa e iletrada.

Muito significativo nesse texto de lançamento é também a fotografia que ilustra a coluna - um retrato do dr. José Pompílio da Hora, apresentado como vice-presidente do Diretório Nacional da Convenção. Por que o retrato do vice-presidente? Possivelmente Abdias não queria sobre si todos os holofotes e, ademais, Pompílio era um dos homens negros mais bem reputados - ainda que não estabelecido - no Rio de Janeiro de então. Voltaremos a esse ponto.

De modo geral, podemos dizer, a partir do que vimos até aqui, que esses escritos revelam um momento em que Abdias do Nascimento, e com ele o movimento negro brasileiro, transita do espaço regional de São Paulo para ocupar uma nova posição nacional na capital da República. Nessa transição, era importante buscar uma nova agenda para o movimento, refazer o diagnóstico do "problema do negro", buscar novos aliados entre intelectuais, artistas e partidos políticos.

No entanto, não há como negar a pobreza intelectual do movimento nesse momento, visível em vários aspectos: ausência de uma teoria sólida sobre os problemas negros; inexistência de uma proposta política autônoma; posição social subalterna dos dirigentes do movimento e, portanto, ausência de legitimidade intelectual. Os integrantes eram despachantes da Alfândega, contadores, estudantes universitários ou, quando muito, profissionais liberais distantes das universidades. A legitimidade intelectual do movimento ainda repousava em antropólogos ou sociólogos, como Gilberto Freyre, Arthur Ramos, Thales de Azevedo e outros intelectuais e artistas brancos.

Estamos nos adiantando. Voltemos ao que pensavam os negros entrevistados pela enquete realizada pela coluna em sucessivas publicações.

\section{O QUE PENSAVAM OS DEMAIS INTELECTUAIS NEGROS}

Em 1946, os redatores da coluna "Problemas e Aspirações do Negro Brasileiro" entrevistaram quarenta pessoas. Vejamos quem eram e o 
que pensavam os demais entrevistados negros, cuja escolha seguiu aparentemente três critérios: 1) participação na Convenção Nacional do Negro, ou seja, potencial liderança ou proximidade com os líderes do movimento; 2) visibilidade intelectual e artística, ou seja, capacidade de influenciar positivamente a opinião pública a favor do movimento; 3) busca em retratar a opinião pública negra. Nesse caso, os entrevistados seriam escolhidos aleatoriamente. Desses três grupos, o último é muito menos representado na amostra.

Comecemos pelas grandes figuras intelectuais ou artísticas negras, razoavelmente independentes do grupo de Abdias.

José Pompílio da Hora, cuja foto aparece na coluna inaugural, era formado em direito pela Universidade de Nápoles e ensinava latim e grego em colégios secundários do Rio de Janeiro. Sua formação escolar aprimorada garantia-lhe não apenas circulação nos meios profissionais da capital, mas também a admiração dos membros da Convenção. O que levaria um negro tão bem-educado e, portanto, com reais chances de aceitação no mundo dos brancos, a unir-se a manifestantes político-raciais? Afinal, desde a Colônia, não apenas os mulatos claros, mas os escuros, e até mesmo alguns poucos pretos bem-educados, evitavam mobilizar-se e protestar contra o preconceito de que eram vítimas, possivelmente porque tais percalços não bloqueavam irremediavelmente suas carreiras. Havia vias abertas de integração e mobilidade.

José Pompílio, recém-chegado da Itália havia pouco mais de um ano, talvez ainda não houvesse tido essas oportunidades; talvez jamais viesse a tê-las ${ }^{8}$. O fato é que, em 1946, era ácido sobre o caráter da democracia brasileira. Valorizava os direitos da cidadania e da efetiva igualdade de oportunidades: "Existem leis que rezam essa igualdade, no futuro próximo outras serão feitas na Constituinte, mas isso quase que nada adianta, visto as leis brasileiras sofrerem da subjetividade quando na sua aplicação" (Diário Trabalhista, 3/2/1946, p. 7). No Brasil, existiria uma falsificação do espírito democrático: em vez de governo do povo, a democracia promoveria a exclusão da população negra, que, segundo ele, representava $75 \%$ da população do país, afastando-a dos altos postos estatais e relegando-a aos cargos subalternos. Em síntese, "democracia para os negros tem sido o direito de limpar ruas, construir prédios onde não podem morar" (ibidem).

Seu irmão Laurindo Pompílio da Hora, também educado na Itália, em carta à coluna sistematiza em que consiste, em sua visão, o problema 
do negro: preconceito de cor que sofre e complexo de inferioridade que interioriza. Sobre o primeiro, cita as barreiras encontradas para o ingresso na carreira diplomática, na Marinha, na Academia Militar, em lojas comerciais etc., ou no acesso a hotéis e a cassinos grã-finos, e arremata: "Aqui nesta terra de negros, mulatos e creoulos, onde as raças se fundem em um só bloco, existe uma luta surda e passiva contra a gente de cor, só por ser de cor" (Diário Trabalhista, 12/3/1946, p. 6). Sobre o segundo, diz: "[...] os nossos negros sentem, aqui na própria terra que redimiram com o próprio sangue [...], um complexo de inferioridade que os afasta das atividades sociais e os diminuem [sic] na luta pelos seus direitos e os traz para um pólo negativo, de onde dificilmente se separam" (ibidem).

Outro intelectual negro, Guerreiro Ramos já despontava como um sociólogo brilhante quando concede uma entrevista a Abdias do Nascimento. Eles se haviam conhecido sete anos antes (1939), quando Nascimento estava residindo pela segunda vez na capital federal e Ramos, cursando a Universidade do Brasil. Os dois tinham maneiras divergentes de pensar a questão negra, sobretudo no que tange à função e à atuação das associações negras. O pensamento de Guerreiro não se afastava muito do mainstream das ciências sociais da época.

Comparando o Brasil com os Estados Unidos, diz: “Deste modo, na grande terra de Roosevelt, o que se chama de problema do negro é um verdadeiro conflito de raças. O negro americano está segregado da comunidade para cuja grandeza ele coopera" (Diário Trabalhista, 24/3/1946, p. 6). Já no Brasil, a situação seria diferente, pois "o preconceito existe, mas é mais disfarçado e o negro sofre uma discriminação menos ofensiva. Entre nós, o preconceito racial perde em importância para os outros dois aspectos da questão: o preconceito de classe e a incompatibilidade de dois mundos mentais distintos" (ibidem).

A "incompatibilidade dos mundos mentais distintos" seria provocada pela cultura compartilhada por negros das camadas populares que, de certo modo, impedia que os negros em ascensão social participassem efetivamente da cultura e do estilo de vida das classes dominantes. $\mathrm{O}$ sociólogo baiano explica esse aspecto e sugere como saída o "branqueamento" sociocultural:

Por outro lado, grande número de negros brasileiros ainda não se incorporou à cultura dominante no Brasil, que é a européia de base latina. Existe uma cultura negra no Brasil com seu sincretismo religioso, seus 
hábitos alimentares, sua medicina de "folk", sua arte, sua moral, etc. O mundo mental destes grupos é incompatível com o das classes dominantes. O negro brasileiro pode "branquear-se", na medida em que se eleva economicamente e adquire os estilos comportamentais dos grupos dominantes. $\mathrm{O}$ "peneiramento" social do homem de cor brasileiroé realizado mais em termos de cultura e de "status" econômico, do que em termos de raça (ibidem).

No que diz respeito à função e à atuação das entidades afro-brasileiras, Guerreiro Ramos afirmava:

Os meios de luta do negro brasileiro não devem ser demagógicos nem sentimentais, têm que ser adequados ao modo como se coloca o problema no Brasil. Penso que os homens de cor não devem jamais organizar-se para combater o preconceito racial. Nesta parte, sua atitude deve ser tanto quanto possível de indiferença e até humorística, nunca de indignação (ibidem).

A resposta de Abdias merece uma citação um pouco longa, mas que dispensa comentários posteriores:

Até aqui o depoimento do prof. Guerreiro Ramos. [sic] Consoante com nossa linha de conduta, respeitamos-lhe com absoluta fidelidade o pensamento e as expressões. Seja-nos lícito agora discordar de uma passagem da sua entrevista, aquela em que diz "[...] os homens de cor não devem jamais organizar-se para combater o preconceito racial. Neste ponto, sua atitude deve ser tanto quanto possível de indiferença e até humorística, nunca de indignação".

Realmente, aí está firmado um princípio negativista. Durante quase todo o período de após abolição, o negro rezou por essa cartilha de assistir de braços cruzados e sorriso nos lábios, à sonegação dos seus direitos de cidadão. Sua decadência atual, em grande parte, pode ser levada à conta desse comportamento contemplativo e resignado. E isso é tão verdade quando se examina o combate ao racismo no Brasil. Este se voltou com maior violência contra o negro e somente amparado na força de suas entidades ele pôde reagir, oferecendo um combate tenaz às forças declaradas ou ocultas que o traziam semi-escravizado. [...] Inegavelmente suas realizações artísticas têm o papel mais importante nesse trabalho de esclarecimento e harmonização social. Porém não fosse a corajosa campanha iniciada por associações tais como a Convenção Nacional do Negro Brasileiro, União Democrática Afro-Brasileira, Associações dos Negros Brasileiros (S. Paulo), União dos Negros Brasi- 
leiros (Porto Alegre), Centro Cruz e Souza (Recife) e muitos outros espalhados pela imensidão do Território Nacional e talvez a estas horas não tivessem alcançado esse avanço na luta anti-social representado pelo discurso do prof. Hamilton Nogueira. [...] É preciso viver no seio das organizações negras para se constatar que o seu espírito de luta não é demagógico nem puramente sentimental. O que há é o aproveitamento das lições sociológicas de Gilberto Freyre e Arthur Ramos, orientando suas atitudes em bases democráticas, sem sectarismos, e longe dos ódios que isolam e separam os homens (ibidem).

O escritor Raimundo Souza Dantas é outro intelectual negro de idéias moderadas, no que diz respeito a temas raciais, ainda que tenha "posto sua cultura e inteligência a serviço da causa do proletariado" (Diário Trabalhista, 1/8/1946, pp. 6-8). Em matéria intitulada "A Questão Negra no Brasil Não É Caso para Partidos", o romancista afirma que "a existência de um 'problema do negro' implica a existência de uma reivindicação específica. Seria um grande erro político, como também alarmante prova do desconhecimento do homem de cor brasileiro, afirmar existir em nossa terra um 'problema do negro'" (ibidem). Por outro lado, isso não significava inexistir o "preconceito de cor" ou o "preconceito racial", que, em sua opinião, não partiria do povo, mas de algumas associações e de determinados setores da sociedade. Só teria sentido, na opinião do entrevistado, falar em problema do negro no Brasil, se a situação vivida por essa população em São Paulo pudesse ser generalizada para todo o país, o que não ocorria. O preconceito, para o romancista, era uma peculiaridade de alguns centros e de algumas organizações.

Souza Dantas, no entanto, ainda que considere não haver lugar para uma luta específica do negro, separada da massa proletária branca, não vê riscos na "organização de homens de cor mais esclarecidos, que se batem por seus direitos", ou seja, não condena o movimento negro, desde que em sua luta reivindicatória, não parta do "princípio de que há no Brasil o preconceito do branco contra o negro". Para ele, a extinção do preconceito viria com o desenvolvimento de uma campanha "da prática positiva da democracia, não somente econômica, mas política e humana" (ibidem). Por fim, o escritor adverte: "A questão do negro no Brasil não é para partidos. E sei bem o que digo, pois digo na qualidade de membro de um grande partido do povo. A questão do negro no Brasil tem que ser resolvida pelo povo" (ibidem). 
Em 15 de agosto, a coluna publica a matéria "O Teatro Experimental do Negro e a Cultura do Povo", na qual anunciava a visita do poeta Solano Trindade, presidente do Centro de Cultura Afro-Brasileiro, junto com outros membros dessa associação, com o intuito de protestar contra a interrupção de uma temporada do TEN no Teatro Fênix. Solano Trindade ressaltava a necessidade de um teatro social realizado por proletários e negros que haviam contribuído significativamente para a formação da cultura nacional. Acusava o Estado de não patrocinar atividades relacionadas à "cultura negra" em um país que se dizia democrático, pois, até em um país onde a democracia era parcial, como nos Estados Unidos, isso ocorreria. O poeta criticava a imagem exótica a que muitas vezes o negro era reduzido:

O negro tem sido estudado como elemento antropológico, etnológico e pitoresco. A macumba, tão condenada pelos burgueses, é para os estudiosos a primeira coisa procurada (e também pelos turistas de casa e além mar). Porém, temos que aproveitar mais do que a macumba, não sou contra ela, considero-a uma das provas de que a cultura negra não é inferior as demais culturas (Diário Trabalhista, 15/8/1946, p. 4).

Trindade lista, então, uma série de atividades e de incentivos que deveriam ser fornecidos a outras formas e modalidades de cultura negra e a suas entidades promotoras, como as apresentações da Orquestra Afro-Brasileira, as peças do TEN e as atividades organizadas pelo Centro de Cultura Afro-Brasileiro. Terminava afirmando que "esse trabalho, essa ajuda, não devia ser exclusivo do negro, mas de todos os homens de bem, brancos ou pretos, amarelos ou judeus, porque os negros do Brasil, em raríssimas exceções, quer [sic], cada vez mais, que desapareçam os últimos sinais do preconceito de cor" (ibidem). Para Solano Trindade, outro homem negro de esquerda, portanto, a democracia americana, que restringia os direitos dos negros, não seria um modelo; do mesmo modo que a cultura negra não estaria restrita às práticas religiosas afro-brasileiras.

Intelectuais negros menos conhecidos, quase orgânicos, para usar a expressão gramsciana, também pensavam de modo semelhante. Em 18 de julho, o entrevistado da coluna foi Luís Lobato. A fala do professor perpassa quatro questões principais: preconceito racial ou de cor; socialização dos lucros das empresas; visão do negro como "povo"; e por fim, a polêmica em torno de um partido exclusivo dos afro-brasileiros. No que diz respeito ao preconceito, Lobato julgava que sua base era econômica, de modo que, "encontrada a premissa no setor econômico 
e considerando que o negro brasileiro é, geralmente, pobre, o preconceito contra o negro toma um aspecto de classe social, não podendo jamais ser resolvido pelo prisma racial" (Diário Trabalhista, 18/7/1946, p. 4).

O professor autodeclarava-se socialista e propunha a participação dos empregados nos lucros das empresas. Afirmando que "o negro é povo" no Brasil" , chegava à conclusão de que "a distribuição igual nos lucros educará o povo, em geral, no sentido evolutivo para o desaparecimento do preconceito de cor, já que este é uma decorrência da própria condição econômica do negro" (ibidem). Lobato também se dizia contra a organização de partidos políticos só de negros. Em sua opinião, essa atitude não passava de uma jogada política de supostos líderes que não tinham compromisso com os negros e procuravam beneficiar a si próprios. Não haveria recursos para realizar tal empreitada, nem uma "filosofia como raça", de modo que esses partidos só serviriam como massa de manobra dos grandes partidos.

Já os ativistas do TEN adotavam, como era de se esperar, um discurso militante. Maria de Lourdes Nascimento, por exemplo, afirmava que os responsáveis pela situação da mulher negra eram os brancos:

Eles nos escravizaram material e espiritualmente. Violentaram a nossa tradição cultural e religiosa, e de tanta pressão psicológica sobre os negros, isto durante tantos séculos, conseguiram perverter-lhe a estrutura moral. Hoje é dificílimo conseguir-se que a massa das mulheres negras estude e lute por um melhor padrão de vida (Diário Trabalhista, 5/4/1946, p. 5).

Maria de Lourdes, natural de Franca, São Paulo, conterrânea de Abdias, com quem estudara na Escola Técnica de Comércio, teria mais tarde, no jornal Quilombo, uma coluna própria para tratar dos problemas da mulher negra.

Em discurso durante as comemorações do 13 de maio de 1946, reproduzido na coluna, Maria de Lourdes traz ao conhecimento de todos a situação em que viviam os negros de sua cidade natal. Os negros de Franca estariam submetidos a situações de discriminação e desprovidos de acesso à educação formal, saúde, moradia e a empregos dignos. A elite econômica e intelectual da cidade seria composta por barões do café ali instalados. Além disso, a discriminação em relação aos negros teria o respaldo policial. Como exemplo, citava o caso do passeio pú- 
blico, que tinha espaços vedados à circulação dos negros. Maria de Lourdes termina seu discurso fazendo um elogio à mestiçagem: “A mulher negra está aqui agora e estará sempre unida em carne e espírito pelo alevantamento e valorização do nosso grande povo brasileiro, o mais belo povo mestiço do mundo" (Diário Trabalhista, 16/5/1946, p. 5).

Nair Gonçalves, jovem atriz formada pelo TEN, por outro lado, expressa o modo amplo como é definido o negro e a postura "trabalhista" do movimento:

\begin{abstract}
A mulher negra, todas elas, de qualquer condição social - digo isso por causa de umas tantas, que por serem formadas, não se julgam mais negras e nem pertencentes a nossa classe de trabalhadores - todas elas devem colaborar com fé e entusiasmo. Somente através desse movimento que estamos levando a efeito, os negros podem ter esperança de um dia terem seus direitos reconhecidos de verdade e não apenas no papel (Diário Trabalhista, 5/4/1946, p. 5).
\end{abstract}

\title{
OS NEGROS DO "POVO"
}

O restante dos entrevistados negros deveria ilustrar o que seria o pensamento dos homens e mulheres comuns. O primeiro a ser ouvido na coluna foi Fernando Oscar de Araújo, apresentado como "pequeno funcionário do DNC" - Departamento Nacional de Comércio. O diálogo é ambíguo e interessante. O entrevistado afirma que não existe "preconceito de cor" no Brasil, mas sim a "covardia da raça negra". A solução para a situação dos negros, de acordo com ele, seria que os "patrícios" tivessem mais confiança própria.

Muitos desses entrevistados negavam a existência de um "problema do negro" no Brasil, geralmente associado a algo semelhante ao que ocorria nos Estados Unidos, mas reafirmavam a existência do preconceito de cor entre nós. Era o caso de Valdomiro Machado, estudante de comércio no Liceu de Artes e Ofícios e datilógrafo do Instituto Brasileiro de Geografia e Estatística - IBGE, que declara à coluna: "Evidentemente não há um problema do negro no Brasil. Eé até lamentável ter-se de falar em problema do negro, simplesmente porque certos indivíduos, em casas comerciais, para falar claro, tentam implantar no país a 'superioridade da raça'" (Diário Trabalhista, 1/2/1946, p. 7).

Quem o entrevistava, provavelmente Abdias, imediatamente procura convencê-lo do contrário: "Demos um aporte explicando ao nosso en- 
trevistado que eram precisamente as desvantagens do negro, por ele mesmo apontadas, que se considerava [sic] como o problema do negro no Brasil, bem diferente do problema racial dos Estados Unidos" (ibidem). O jovem datilógrafo teria sido convencido pelo repórter.

O estudante de medicina Walter Cardoso afirma que, no Brasil, não se trata "apenas de um problema de raça ou de classe, mas sim de um problema nacional". A solução viria através da educação formal para o negro, que, por meio dela, poderia elevar-se social e economicamente, além de romper com seu sentimento de inferioridade, pois, em sua opinião, o verdadeiro problema estava na situação educacional e econômica da população afro-brasileira. Ele termina a entrevista em tom otimista, sugerindo que o mundo, após o fim da Segunda Guerra Mundial, vivia um momento de afloramento democrático e que o Brasil não ficaria fora disso (Diário Trabalhista, 21/3/1946, p. 6).

Em 16 de fevereiro, o entrevistado da coluna foi Adhemar Homero, de ocupação não declarada, dizendo apenas que foi estudante de direito na juventude. Homero tece as mesmas críticas à situação a que foram relegados os negros, citando algumas instituições que vedariam a entrada da população "de epiderme mais escura" - o Itamaraty, a Escola Naval, a Aeronáutica e o Exército. Para o entrevistado, "cada vez mais se acentua o malfadado preconceito de cor. Não adianta querer negá-lo. É verdade que usam aproveitar alguns mulatos de talento em cargos de destaque para tentar mascarar a verdade. Porém, esta é mais forte que todas as camouflages" (Diário Trabalhista, 16/2/1946, p. 7).

O depoimento mais interessante de todos foi dado por Aladir Custódio, ascensorista de um prédio no centro do Rio de Janeiro. Apresentado como poeta, Aladir demonstra conhecimento da poesia de Langston Hughes, assim como das idéias de Roquette Pinto e de Euclides da Cunha. A entrevista é exemplar ainda porque ele discorre sobre todos os tópicos que vinham insistentemente sendo abordados pela maioria das personalidades questionadas pela coluna. O poeta critica o modo como foi feita a Abolição, "uma grande vitória do nosso povo sobre os opressores escravocratas" (Diário Trabalhista, 8/9/1946, p. 6), abandonada a seguir pela República, que, em vez de estabelecer um plano de elevação moral, econômica e cultural dos ex-escravos e de seus descendentes, teria amparado e incentivado o progresso dos imigrantes.

Em seguida, Custódio ataca aqueles que viam a miscigenação como um dos motivos do nosso atraso. Citando Roquette Pinto, con- 
tra-argumenta que o nosso grande problema era a educação: "O homem no Brasil não precisa ser substituído, mas educado" (ibidem). Busca ainda em Os Sertões, de Euclides da Cunha, um exemplo de como o homem brasileiro mestiço era tenaz e valoroso.

Questionado sobre a existência ou não de preconceito racial no Brasil, Custódio afirma: “No Brasil - por força da nossa própria formação étnica - o preconceito nunca chegou a alcançar um caráter tão grande como nos Estados Unidos, onde existe uma 'colored line' que limita e define a raça e a cor" (ibidem). Por outro lado, o preconceito vigente no Brasil seria "traiçoeiro e estúpido", processando-se nas carreiras diplomática e militar, nas casas noturnas e no comércio. Conclui que "nisto há qualquer coisa do poema 'Eu também sou a América', do consagrado poeta negro norte-americano Langston Hughes: 'Quando chegam visitas, eles mandam-me comer na cozinha'” (ibidem).

Custódio volta-se para a situação dos negros em São Paulo e cita o incidente ocorrido em 1944 na rua Direita onde se tentou proibir a circulação de negros e em seus arredores ${ }^{10}$. Para ele, isso seria, na verdade, um exemplo de preconceito econômico, mascarado de "preconceito de cor". Em sua opinião, ecoando talvez as idéias de Mário de Andrade (1938), o preconceito era uma superstição que só a educação e uma maior aproximação social e cultural poderiam com o tempo extinguir. Também seria necessário evitar a formação de quistos raciais, sobretudo em partidos políticos, algo que afetaria nossa tradição de tolerância. A entrevista termina com o poeta exaltando os trabalhos das associações afro-brasileiras, pois estas não segregavam o negro, mas o colocavam mais próximo, cultural e socialmente, do branco. Auxiliariam no combate às restrições que impediriam a marcha "de uma nação pelo caminho largo da Democracia" (Diário Trabalhista, 8/9/1946, p. 6). O poeta, humilde ascensorista, mas lido e refinado, pensava como um homem bem-educado de seu tempo.

Destoando desse tom moderado, a empregada doméstica Arinda Serafim inicia a entrevista referindo-se à situação de desamparo do negro após a Abolição para criticar a atitude do governo no dia de retirar famílias, em sua maioria negras, do morro do Jacarezinho, ação que Arinda chamou de "cerco do Jacarezinho". Ela afirma ser "necessário que a democracia se torne realidade também nos morros" (Diário Trabalhista, 13/2/1946, p. 4), retomando aqui uma das palavras de ordem do protesto negro e do país naquele momento. Arinda valoriza a educa- 
ção como meio de o negro buscar consciência de si como homem e cidadão. A ausência de educação é entendida como geradora do preconceito de raça, de cor e do complexo de inferioridade. Por fim, interpretando livremente Arthur Ramos, a doméstica afirma que o preconceito de cor e o complexo de inferioridade são problemas que surgem em virtude da divisão da sociedade em classes. Ambos se extinguiriam a partir da liquidação das diferenças econômicas.

Outro depoimento interessantíssimo foi o segundo prestado por Fernando Oscar de Araújo, em que discordava das conclusões de Donald Pierson (1900-1995) sobre a não existência de "preconceito racial" no Brasil. Araújo afirma ter lido uma reportagem de Justino Martins intitulada "Gafieiras do Brasil", publicada na Revista do Globo, de Porto Alegre, em que o professor norte-americano traça um "paralelo" entre a situação do negro no Brasil e nos Estados Unidos:

Nos Estados Unidos os negros, como grupo biológico diferente dos brancos, estão se multiplicando gradativamente, enquanto no Brasil, o mesmo caso se verifica em sentido contrário, isto é, há uma notável tendência para a pressão do subtipo comum - o mulato. Especialmente no nordeste do território brasileiro, onde os negros estão sendo dizimados biologicamente pelos mulatos e estes pelos brancos... Conclusão: O preconceito existe no Brasil, mas é de classe existe [sic] e não de raças (Diário Trabalhista, 17/3/1946, p. 6).

Araújo nega que tenha a pretensão de discordar de Pierson, mas não aceita sua conclusão e argumenta: se, por um lado, aos negros americanos era negada a integração na sociedade branca americana, por outro, haviam construído "um verdadeiro país de negros", no qual tinham o direito de se educar para atuar nos mais diversos setores - ciência, literatura, artes, finanças etc. Já no Brasil, a situação do "povo de cor" seria de extrema decadência. $\mathrm{O}$ entrevistado conclui com uma pergunta: "Sob o ponto de vista da evolução, do progresso e da felicidade dos pretos, qual a melhor solução, a norte-americana ou a brasileira?"; e arremata, enfaticamente: "Julgo que o professor não estudou tão profundamente o preconceito no Brasil ou ao contrário não quis ser indiscreto... O preconceito de cor está aí lanhando as cores [sic] do negro para quem quiser ver. O mais não significa toda a verdade [...]" (ibidem).

Teriam realmente existido todos esses "homens do povo" ou teriam sido, pelo menos alguns, personagens ficcionais de nossos colunistas, a expressar críticas que eles não se sentiam com autoridade intelectual 
para sustentar em público? As discrepâncias entre as primeiras declarações de Fernando Oscar de Araújo, prestadas em 18 de janeiro, e as que acabamos de ler, de 17 de março, são tão gritantes que cabe a indagação sobre a existência real desse personagem.

\section{OS POLÍTICOS BRANCOS}

O Partido Comunista Brasileiro - PCB foi o primeiro a tentar uma aproximação com o TEN sem, entretanto, nunca ter vencido a resistência dos negros, que procuravam impor uma agenda própria, independente "da luta do proletariado". As relações do TEN com a UNE, por exemplo, foram bastante conflituosas, assim como foram sempre difíceis as relações do TEN com os intelectuais negros ligados ao Partidão, como Edison Carneiro, Souza Dantas e Solano Trindade.

No plano da política partidária, em 1946, um dos grandes aliados do movimento que crescia em torno do TEN era o senador Hamilton Nogueira ${ }^{11}$, alcunhado de "senador dos negros". Em entrevista publicada no Diário Trabalhista, o senador dizia que "os pretos não estão criando nenhum problema" e defendia os líderes negros acusados de estarem "criando um problema que não existiria no Brasil". Se por um lado a defesa refletia a preocupação de acalmar a opinião pública, por outro, dá a noção exata da negociação em que o movimento negro tinha de se empenhar. Comprovar a existência de um "problema do negro" no Brasil significava também buscar a tutela de figuras importantes no mundo político e social.

Nogueira encontrava-se no início de sua carreira política. Após a deposição de Vargas, em outubro de 1945, elegeu-se senador do Distrito Federal à Assembléia Nacional Constituinte pela legenda da União Democrática Nacional - UDN. De acordo com Barbosa (2004:60), teria participado da Convenção Nacional do Negro em 1945. Em 21 de fevereiro de 1946, o então senador proferiria um discurso na Constituinte propondo a criminalização das práticas de discriminação por cor ou raça, endossando uma das reivindicações do manifesto. O Diário Trabalhista, ao destacar o pronunciamento do senador Nogueira, republica na íntegra o manifesto da Convenção Nacional do Negro Brasileiro, que, em determinado trecho, afirma:

Temos consciência da nossa valia no tempo e no espaço. O que nos faltou até hoje foi a coragem de nos utilizarmos dessa força por nós mesmos e segundo a nossa orientação. Para tanto é mister, antes de mais 
Antonio Sérgio Alfredo Guimarães e Márcio Macedo

nada, nos compenetrarmos, cada vez mais de que devemos estar unidos a todo o preço, de que devemos ter o desassombro de ser, antes de tudo, negros e como tais os únicos responsáveis por nossos destinos em consentir que os mesmos sejam tutelados ou patrocinados por quem quer que seja. Não precisamos mais de consultar nossos direitos, da realidade angustiosa de nossa situação e do cumpliciamento de várias forças interessadas em nos menosprezar e condicionar, mesmo, até o nosso desaparecimento (Diário Trabalhista, 30/4/1946, p. 5).

Nogueira, no entanto, não era a UDN. Em 1946, Abdias já se aproximava do PTB - ao qual se filiaria mais tarde -, partido que permanece durante todo o período democrático melhor sintonizado com os "problemas e aspirações do negro brasileiro". Não foi, contudo, uma aproximação fácil. A esse respeito, o texto "A Bancada Trabalhista Dá Todo o seu Apoio às Reivindicações do Negro", que tinha como subtítulo "Entrevista-relâmpago na Sede Central do PTB - Como falaram ao 'Diário Trabalhista' os deputados Segadas Vianna, Manoel Benício Fontenelle, Rubens de Mello Braga, Baeta Neves e Benjamin Farah", é digno de nota. Apesar de o título sugerir que o PTB apoiava as reivindicações dos negros, a realidade era um pouco diferente, como deixava entrever o texto da matéria.

O primeiro deputado interpelado, Baeta Neves, esquiva-se da pergunta que lhe dirige o repórter, deixando-a ao deputado Rui de Almeida. Este responde ao jornal que em suas veias corre sangue negro, alicerce da nacionalidade. Quando questionado sobre as restrições sofridas pelos negros nas Forças Armadas e na diplomacia, responde que, se aparecesse um caso concreto, deveria ser levado ao conhecimento da Câmara. O próximo deputado abordado, Rubens de Mello Braga, diz desconhecer o problema do negro por ser do Paraná, onde não haveria restrições ao afro-brasileiro. O terceiro, Segadas Vianna, evita o repórter com andar apressado, mas não sem deixar um recado: "Confirmo tudo o que já disse antes". O colunista trata de explicar a posição do deputado que, por várias vezes, falara em favor das causas negras. O quarto político, Benjamin Farah, não sabe o que responder e diz que falará com o repórter mais tarde. Baeta Neves, que primeiramente havia escapado, oferece uma saída para o problema do negro, que soa, no mínimo, cômica:

Reitero que já tive oportunidade de dizer à imprensa sobre o assunto, isto é, que apresentarei à Câmara uma legislação especial em que fique demonstrado que em nosso país não existe de fato o preconceito de cor, 
raça ou religião. Com essas leis se coibirá o abuso dos mais reacionários, que ainda hoje prejudicam essa grande parcela do povo brasileiro (Diário Trabalhista, 8/2/1946, p. 5).

Quando o repórter já se ia, um último político, o deputado Manoel Benício Fontenelle, chama-o e diz que, quando não houvesse mais ninguém para defender o negro na Câmara, ele o faria.

Essa cena ilustra a subalternidade do tema para os políticos. Talvez, por isso, no TEN, houvesse atores, como Ruth de Souza, que defendiam uma postura autônoma do movimento em relação aos partidos políticos. Depois de uma solenidade de agradecimento ao senador Hamilton Nogueira, disse a jovem atriz:

Em parte não gostei da maneira como decorreu a homenagem mais do que justa ao senador Hamilton Nogueira. Estávamos reunidos para prestar uma homenagem ao defensor da raça e não a um partido. Alguns trouxeram atitudes partidárias. Falo de irmãos negros, naturalmente. Atitude realmente lamentável, pois foi quebrado o espírito de união que deve presidir a nossa luta (Diário Trabalhista, 5/4/1946, p. 5).

A busca de Abdias do Nascimento por um partido político termina em novembro de 1946, com a criação de um Diretório Negro no PTB (ver Quadro 1). O PTB decide também lançar um candidato a vereador que tenha vínculos estreitos e liderança na comunidade negra do Rio de Janeiro.

\section{OS INTELECTUAIS BRANCOS}

O esforço de Abdias em aproximar-se da elite intelectual brasileira, seja para legitimar seu movimento, seja para encontrar aliados no mundo intelectual, evidencia-se na lista dos entrevistados pela coluna "Problemas e Aspirações do Negro Brasileiro": Rossine Camargo Guarnieri, Joaquim Ribeiro, Arthur Ramos, Rômulo de Almeida, Gentil Puget, Thales de Azevedo, Herman Munoz Garrido, Ricardo Werneck de Aguiar. O que pensavam esses intelectuais sobre o problema do negro? Vejamos alguns deles.

O primeiro a ser entrevistado, Arthur Ramos, era também o mais próximo, apresentado nesses termos:

O Prof. Arthur Ramos, como autêntico homem de nosso século, que não admite "torres de marfim" diferenciadas da vida cotidiana da humani- 
Quadro 1

Chamada para Reunião do Diretório Negro do РТВ

\section{Em Defesa dos Afro-Brasileiros \\ Preconceito de Cor e Complexo de Inferioridade, Dados Negativos da Nossa Evolução \\ Reúne-se Hoje Novamente o Diretório Negro Petebista}

Estava tardando muito que um partido político cuidasse seriamente de reparar a grande injustiça que pesa sobre a raça negra, desde os dias da Abolição da Escravatura. Após trabalharem vários séculos sob o regime da opressão e da ignomínia, sem ter nada que não fosse um catre pobre na atmosfera dramática da senzala, os negros saíram para a liberdade, em 1888, completamente desprevenidos para enfrentar a luta pela vida que se lhes defrontava. Não tinham instrução, não tinham meios econômicos de subsistência, não tinham educação social e profissional, enfim, não se encontravam absolutamente em condições de enfrentar, no mesmo pé de igualdade, a concorrência dos imigrantes que para cá afluíam garantidos pelas leis e com a assistência direta dos seus respectivos países de origem.

Assim desarmados e desamparados, o negro só tinha um caminho a seguir: o caminho da decadência e da degradação. Foi o que se viu. As favelas, os hospitais, as prisões e os manicômios passaram a ser os locais mais freqüentados pelos descendentes da raça heróica e produtiva que alicerçou com suor e sangue a estrutura econômica do Brasil. Não fosse a notável capacidade de resistência ao sacrifício, não fosse a fertilidade espantosa do ventre da mulher negra, e talvez a estas horas estivessem quase extintos entre nós os remanescentes do povo heróico de Zumbi, Henrique Dias e Patrocínio.

Estas foram as origens do atual problema do negro brasileiro, do qual com o correr do tempo se aprofundam o preconceito e o complexo de inferioridade, que são os dados mais negativos da evolução social, baseada na miscigenação e numa nítida harmonia de raças. Devemos, assim, envidar todos os esforços para que amanhã esse problema não adquira contornos mais prejudiciais ainda, ou acentos de violência como nos Estados Unidos da América do Norte. E foi pensando acertadamente que o Partido Trabalhista Brasileiro resolveu criar o seu Diretório Negro, dando oportunidade para que os próprios interessados debatam suas questões, até mesmo no seio da Câmara Municipal, consignando em sua chapa de vereadores um lugar para a representação dessa minoria étnica. Hoje, às 18 horas, na rua Álvaro Alvim, 59, 1ำ andar, haverá reunião pública do Diretório Negro, para a qual estão convidados todos os interessados.

Fonte: Diário Trabalhista, 28/11/1946, p. 5. 
dade, tem participado dos movimentos pró-reivindicações democráticas e a sua atuação social entre a gente de cor lhe conferiu o título de "amigo número 1 do negro", expressão muito comum entre a coletividade afro-brasileira (Diário Trabalhista, 9/2/1946, p. 4).

Questionado se existiria ou não um problema do negro no Brasil, termo oriundo da tradição de estudos ao qual se filiava, é categórico: "Não existe só um problema - respondeu-nos S.S. - mas vários problemas do negro no Brasil: sociológico, antropológico, biológico etc." (ibidem).

Rossine Camargo Guarnieri compara a situação do negro em diferentes regiões do país. São Paulo é retratada por ele como a cidade em que o preconceito contra os negros era explícito, mas também onde o ativismo negro havia feito suas maiores conquistas. O poeta vê a questão racial como subordinada à luta de classes. Em sua opinião, o negro deveria juntar-se aos "irmãos proletários de todas as raças", "ingressar nas organizações de massa", pois, só "marchando com a classe operária", conseguiria libertar-se do preconceito que o afligia. No final da entrevista, Guarnieri reverencia a Convenção Nacional do Negro como "o melhor que se fez num sentindo orgânico" em relação aos negros nos quadros da democracia. Os "partidos de massa" deveriam inserir como reivindicações na Constituinte todos os pontos levantados pelo manifesto da convenção (Diário Trabalhista, 25/1/1946, p. 7).

Dois dias depois dessa entrevista, o professor Joaquim Ribeiro reafirmava que existia preconceito contra os negros. Sua origem, contudo, seria social e econômica, e não racial. A Abolição teria sido incompleta. Segundo o professor, a reabilitação dos negros deveria ser iniciativa do Estado, a partir de um "serviço de assistência social a [sic] família negra" e de um programa que visasse à "assistência cultural ao estudante negro" (bolsas de estudo). Tanto negros quanto brancos são vistos por ele como sofrendo de certa patologia racial. Enquanto nos últimos ela se manifestaria pelo "preconceito racial", nos primeiros se configuraria em um "complexo de inferioridade":

Este é o mais delicado. Se o branco, desrazoadamente ainda guarda vestígios do preconceito racial, o negro, por sua vez, também sofre de "complexo de inferioridade" por se saber descendentes de escravos. É necessário que se faça, entre eles, forte campanha de "higiene mental" a fim de extinguir os resquícios dessa dolorosa "vivência" que já pertence ao passado (Diário Trabalhista, 27/1/1946, p. 7). 
Em 28 de fevereiro, o entrevistado foi Rômulo de Almeida, economista de formação e amigo de Abdias desde as fileiras integralistas. Questionado se existiria ou não um problema do negro no Brasil, responde:

Opino que sim, e acho contraproducente ocultá-la ou desconhecê-la, embora esta atitude seja para muitos inspirada no desejo de que não houvesse ou no intento de contribuir para que a sociedade a esqueça. Em grande parte o problema do preto é o problema do povo, do povo pobre. Mas está longe de ser apenas isto. Resiste também um preconceito que tem sido quiçá reforçado por alguns fatores: as correntes imigratórias provindas dos povos com sensível consciência de superioridade racial, os reflexos dos pruridos racistas e a coincidência de se sedimentarem os pretos na camada de inferior condição educacional, técnica e econômica, fato em que muitos encontram a "evidência", um "documento" de inferioridade da raça (Diário Trabalhista, 28/2/1946, p. 7).

Para Rômulo, a questão racial confundir-se-ia, muitas vezes, com a questão social. O preconceito, por sua vez, manifestar-se-ia de forma mais forte nas relações afetivas, sendo o casamento inter-racial um tabu para pessoas das classes mais abastadas. Entre a população mais pobre, predominantemente negra ou mestiça, esses impedimentos seriam menores.

“A solução essencial já está encaminhada pela melhor tradição brasileira, que nunca levou muito a sério o preconceito" (ibidem), conclui Rômulo, conclamando os afro-brasileiros a agir de maneira mais enérgica quando forem vítimas de preconceito.

A entrevista de Thales de Azevedo ganhou mais destaque: "A discriminação de cor é fato infelizmente verdadeiro no Brasil". Depois de distinguir "discriminação de cor" de "preconceito racial" como o fizera anteriormente Frazier (1942), Thales afirma que há "discriminação de cor" nos mais diversos âmbitos da sociedade baiana, como no trabalho, na educação e no lazer, ainda que, contra os menos escuros, a discriminação seja mais branda ${ }^{12}$. Também nos relacionamentos afetivos das classes altas haveria a tendência a não se aceitarem casamentos ou uniões entre cônjuges de cores muito diferentes. Para Thales,

Em resumo, a discriminação de cor é fato infelizmente verdadeiro no Brasil, embora sem rancores nem radicalismos. Para superá-la, como é necessário, devemos esforçar-nos por elevar os padrões econômicos, educacionais e biológicos de todo o nosso povo não fazendo separações 
em grupos de "Henriques" e de brancos de tão precária pobreza como somos nós, com poucas exceções. Também é preciso resistir dedicadamente às tentativas de incitamento à luta de classes que agentes políticos e pesquisadores de temas afro-brasileiros andam a provocar sob os mais variados disfarces. Isso é tanto para os intelectuais sinceramente humanos, patriotas e democratas (Diário Trabalhista, 10/4/1946, p. 4).

O redator, por sua vez, finaliza a matéria de maneira muito parecida, ressaltando as palavras do "renomado acadêmico e cientista" sobre a existência de "discriminação de cor" na Bahia. Em face do consenso científico e popular sobre a inexistência desse tipo de problema "nas terras do Senhor do Bonfim", arremata desafiadoramente: "Porém agora, o que dizer em face desta tremenda denúncia do professor Thales de Azevedo? Que respondam os negros, brancos ou 'brancos da Bahia' [...]" (ibidem).

O último intelectual branco entrevistado pela coluna, em 1946, foi Ricardo Werneck de Aguiar, responsável pela tradução da peça de Eugene O'Neill, O Imperador Jones (1920), encenada pelo TEN no ano anterior. Quando questionado sobre a existência ou não de um problema do negro no Brasil, a resposta de Aguiar foi que o problema do negro estava vinculado ao "grande problema humano universal"; o negro era uma criatura humana, e não membro de uma raça. O problema do negro seria, antes de tudo, um capítulo do grande problema social. O tradutor acreditava na existência do preconceito de cor, resquício da sociedade escravista, patriarcal e agrícola responsável pela "desvalorização do trabalho", que atingia os indivíduos de todas as classes no Brasil.

Ainda de acordo com Aguiar, as soluções para esses problemas caberiam a economistas, sociólogos e ao Estado. Aguiar concordava com a existência de restrições deliberadas a negros em determinadas áreas, como a carreira militar ou diplomática, mas discordava de que esse fato deveria se tornar motivo de reivindicação dos afro-brasileiros. $\mathrm{O}$ tradutor acreditava, sim, "na valorização do trabalho e do trabalhador [...] através da união, disciplina e luta das classes operárias em prol da melhoria dos seus padrões de vida" (Diário Trabalhista, 16/8/1946, p. 3). Questionado a respeito dos movimentos negros brasileiros e a campanha pela segunda Abolição, o tradutor afirmava que o movimento vinha sendo bem conduzido, pois se processava mais no terreno cultural e artístico, não estabelecendo "confusões" nem criando questões alheias ao quadro geral dos nossos problemas raciais. 


\section{A DEMOCRACIA RACIAL NEGRA}

Como vimos, foram raros os momentos, em 1946, em que o protesto negro atingiu graus de radicalidade que pusessem em risco idéias bem consolidadas sobre a harmonia racial brasileira e o caráter mestiço e miscigenado do povo brasileiro. Encontramos esses raros momentos em desabafos de homens como Pompílio da Hora, que enfatizava a desigualdade sociopolítica entre negros e brancos e punha em xeque o caráter subordinado da democracia brasileira para os negros, ou em Abdias do Nascimento, quando duvidava de nossa "democracia de cor", como na passagem a seguir:

A fictícia igualdade social de todos os brasileiros, a nossa decantada democracia de cor, tão engalanada de lantejoulas e jóias de ouropel, não resistiu à análise fria e imparcial da ciência. A sociologia e a antropologia falaram através de autoridades como Gilberto Freire e Artur Ramos, denunciando os atentados criminosos sofridos pelos negros em seu patrimônio espiritual e cultural. Muitos outros observadores e pesquisadores ergueram sua voz, entre os quais se destaca o sincero e desassombrado jornalista R. Magalhães Jr. condenando os processos ignóbeis forjados para ainda uma vez mais escravizar os descendentes do povo africano (Diário Trabalhista, 9/3/1946, p. 6, ênfases dos autores).

No entanto, mesmo nesses momentos, a autoridade intelectual de figuras como Gilberto Freyre ou Arthur Ramos, que lutavam pela "democracia racial", era utilizada para legitimar as posições radicais.

Muitas idéias-chaves para a formação da identidade afro-brasileira circularam intensamente entre ativistas e intelectuais negros brasileiros no período pós-Abolição. Algumas, insistentemente veiculadas nos anos 1930, retêm nossa atenção porque permanecem importantes para a política étnica atual.

A primeira foi magistralmente exposta por Mário de Andrade (1938) em um pequeno artigo intitulado "A Superstição da Cor", no qual argumenta que a cor da pele seria uma característica irrelevante dos seres humanos, não fosse a cor preta objeto de intensa superstição nas civilizações humanas, sempre associada à escuridão e ao mal. Em conseqüência, os homens pretos sofrem pela ignorância e superstição associada à sua cor. Somente a educação dos povos poderia pôr um fim a tal superstição, já que a cor é um simples acidente na condição humana. Essa idéia vocalizada por Mário é ainda influente no cotidiano e no 
senso comum brasileiros, mas, nos anos 1940, tinha muito mais vigor e curso, como atesta o ditado "a cor é apenas um acidente".

Outra idéia muito influente foi expressa por Donald Pierson (1942) em sua versão liberal. A classe, e não a raça, é a categoria que explica o "preconceito de cor" existente no Brasil. Isso significa, em última instância, que o preconceito de que os negros se ressentem se deve a diferenças de oportunidades econômicas e culturais entre brancos e negros. Em sua versão marxista, expressa pela primeira vez por Luis Aguiar Pinto (1953), é a exploração capitalista o principal problema que desafia os negros brasileiros, o preconceito de cor sendo apenas sua face alienada. Para os marxistas, somente uma frente comum dos explorados, brancos e negros, poderia fazer face à situação a que os negros, ou seja, grande parcela do povo brasileiro, estavam sujeitos. Praticamente todos os entrevistados por Abdias em 1946 repetiram ou se referiram a esse argumento qualificando-o ou desqualificando-o.

A natureza mestiça do povo brasileiro é a terceira idéia-chave, quase perene, nos debates e nos discursos de negritude dos anos 1940. Provavelmente vem das lutas pela Independência, sendo difícil apontar um autor exemplar que a tenha expressado. Poderíamos, entretanto, citar Von Martius (1845). No meio negro, essa idéia adquiriu um novo contorno no começo do século XX, quando autores mulatos, como Manuel Querino (1980), passaram a se referir ao mulato como o tipo genuinamente brasileiro. Uma importante variante dessa idéia, encontrada por nós nas entrevistas de 1946, foi enunciada por Luís Lobato, um professor negro do Rio de Janeiro, que definiu o povo brasileiro como negro, algo que seria retomado e plenamente desenvolvido politicamente por Guerreiro Ramos nos anos 1950, em sua Introdução Crítica à Sociologia Brasileira.

As duas próximas idéias são contemporâneas do material que examinamos. A segunda Abolição, que floresceu durante a FNB, e o elogio à cultura africana, como tendo qualidades emocionais e artísticas distintas e superiores, que devemos à influência da negritude francesa e dos antropólogos culturalistas.

A segunda Abolição é a um só tempo diagnóstico e programa de ação. A Abolição de 1888 teria deixado os ex-escravos e o povo negro em geral sem nenhuma proteção do Estado, ao mesmo tempo livres e despossuídos, escorraçados do mercado de trabalho pelos imigrantes europeus, que os substituíram, caindo facilmente na pobreza e na imorali- 
dade. A segunda Abolição seria o momento de redenção e de integração dos negros à nação brasileira, por meio da educação e da restauração moral. Segundo Karin Kössling (2000), tal idéia foi elaborada primeiramente pelos integralistas paulistas antes de ganhar a imaginação dos ativistas negros dos anos 1930 e 1940.

O elogio à herança africana no Brasil tem como precursores Nina Rodrigues (1862-1906) e Manuel Querino (1851-1923), mas encontrou nos estudiosos dos costumes africanos, do candomblé e da aculturação negra no Brasil seus principais porta-vozes. Paralelamente a esses, mais bem situados nos meios acadêmicos, intelectuais negros como Ironides Rodrigues, um dos entrevistados de 1946, difundiram as idéias dos modernistas europeus e dos militantes da negritude sobre a emoção, a beleza e o refinamento estético da arte e das civilizações africanas. No entanto, há de se precisar que a influência dos modernistas europeus chegou aqui bem antes (em 1920) - e foi decisiva para o modernismo brasileiro - do que a dos ativistas da negritude francesa, que só depois da Segunda Guerra Mundial passou a ser relevante, e ainda assim limitou-se ao meio negro.

Todas essas idéias brevemente mencionadas reverberaram de forma intensa nas entrevistas que analisamos. Constituíram, na verdade, a matéria-prima para o futuro discurso negro sobre a democracia racial.

Até os anos 1940, essas idéias estavam agrupadas em, pelo menos, duas constelações discursivas. A primeira, muito influente na Bahia e no norte do Brasil em geral, amalgamava a idéia do Brasil como nação mulata e a valorização da herança africana como folclore afro-brasileiro, assim como a negação do preconceito de raça no Brasil. A segunda, desenvolvida sobretudo pelo movimento negro em São Paulo, enfatizava a segunda Abolição, a necessidade de os negros se livrarem das superstições e dos costumes africanos, trabalhando unidos pela redenção e pelo soerguimento moral do povo negro. O discurso sobre o preconceito de cor era ambíguo. Muitas vezes era apenas a negação do racismo dos brancos e a afirmação de que o preconceito era alimentado pelos mulatos e mestiços claros. Ao mesmo tempo, foi em São Paulo que se desenvolveu, na política, o sentimento de orgulho de se pertencer à raça negra.

Como essas constelações foram suplantadas em meados dos anos 1940? Muitos intelectuais e ativistas estiveram na prisão durante o Estado Novo, sobretudo integralistas e comunistas. Foi na prisão, por 
exemplo, que Abdias se familiarizou com algumas idéias decisivas para a reconstrução democrática de 1945 e 1946, e foi na conjuntura de redemocratização que Abdias, Camargo, Sebastião, Ironides e outros também ativos na FNB, como Francisco Lucrécio e Correia Leite, se reorganizaram para influenciar a redação da nova Constituição brasileira. O fato político novo era a presença ativa do movimento negro no Rio de Janeiro, que antes se limitara quase exclusivamente a São Paulo. Qual o teor do novo discurso negro?

Ainda que, em 1946, a segunda Abolição fosse central ao discurso de mobilização dos negros, novas idéias relativas à democracia eà injustiça raciais foram desenvolvidas. A democracia norte-americana, sempre vista como modelo, era encarada como incompleta e insuficiente pela unanimidade desses ativistas e intelectuais, pois não garantia plena igualdade de direitos aos negros. Para alguns, como o advogado negro Pompílio da Hora, também a democracia no Brasil estava truncada e limitada, uma vez que as leis não eram cumpridas.

No entanto, essa crítica radical às desigualdades raciais teve como conseqüência apenas a proposição de maior universalidade das leis. A totalidade dos intelectuais brancos e negros entrevistados por Abdias, mesmo reconhecendo os direitos de os "homens de cor mais esclarecidos" se organizarem politicamente, era contrária à criação de um partido negro. De modo geral, todos advogavam que o Estado brasileiro deveria melhorar e universalizar a educação e a saúde públicas, assim como apoiar fortemente a valorização da cultura afro-brasileira.

Além da resistência à criação de um partido político ou mesmo de diretórios partidários negros, também foi rechaçada a implementação de políticas públicas, como bolsas de estudos, que privilegiassem negros em relação a brancos. Tal resistência vinha tanto da esquerda, sobretudo de membros ou simpatizantes do PCB, para quem a organização da classe operária e sua indivisibilidade eram quase dogmas, quanto dos conservadores, para quem o negro sofria de inferioridade se não biológica, ao menos cultural, sendo responsáveis por sua própria sorte.

A resposta dos colunistas liderados por Abdias foi jogar luz sobre as relações raciais em outras regiões do país, além de Rio de Janeiro e São Paulo. Em 12 de outubro, a manchete da coluna "Problemas e Aspirações do Negro Brasileiro" fala em "O Negro em Marcha" e "O Movimento Negro em Todo o Brasil", trazendo notícias de Pernambuco, Rio Grande do Sul e Alagoas, além de São Paulo. Do mesmo modo, idéias 
consensuais, legitimadas pelas ciências sociais, sobre a inexistência do preconceito racial no Brasil eram sorrateiramente minadas por declarações de pessoas do povo entrevistadas pela coluna.

Na maioria das vezes, porém, Abdias e seus companheiros estavam na defensiva, tentando convencer a opinião pública de que havia realmente um "problema do negro" no Brasil e de que eles não o estavam criando do nada. Três pontos eram regularmente citados como compondo o "problema do negro": alienação econômica e social dos negros na pós-Abolição; preconceito de cor e inaceitável discriminação dos negros no comércio, nas Forças Armadas e no Itamaraty; o sentimento de inferioridade dos próprios negros.

Os remédios para o "problema do negro" seriam, em primeiro lugar, a mobilização dos próprios negros e sua representação política autônoma no sistema eleitoral, como é expresso no Manifesto à Nação Brasileira; em segundo, a inovação cultural - o projeto de desenvolver uma moderna cultura negra tanto popular quanto erudita, em vez de tratar a cultura negra como folclore ou objeto de estudos antropológicos. $\mathrm{O}$ TEN, a Orquestra Afro-Brasileira, de Abigail Moura, e o Centro de Cultura Afro-Brasileiro, de Solano Trindade, eram as melhores expressões dessa vontade, assim como o eram os jornais negros de São Paulo, como A Alvorada e Senzala, e a coluna de Abdias no Diário Trabalhista, depois transformada na revista mensal Quilombo.

Representar-se no sistema político, entretanto, era realmente difícil. O grande desafio consistia justamente em construir alianças políticas no Brasil sem aceitar a proteção paternalista dos brancos. Depois do rompimento com os comunistas, que preferiam um Teatro Popular, voltado ao povo em geral, ao teatro negro, a estratégia de Abdias foi aproximar-se do PTB. Primeiro, como vimos, o grupo do TEN encontrou no senador branco Hamilton Nogueira um protetor, mas, no final de 1946, Abdias já fora capaz de criar, na Assembléia Municipal do Rio de Janeiro, um Diretório Negro do PTB.

Em termos ideológicos, todos os esforços do movimento concentraram-se em diferenciar a situação dos negros brasileiros da dos norte-americanos, buscando assim afirmar a especificidade do preconceito racial no Brasil, em vez de negá-lo. Não era uma tarefa fácil, uma vez que caberia à ciência social - e não à política - fazer o diagnóstico, e o movimento negro não contava com cientistas sociais em seus quadros. Os líderes negros estavam longe não apenas das posições universitá- 
rias, mas também das posições sociais de prestígio; como já mencionado, eram contadores, delegados de polícia, pequenos servidores públicos, estudantes e, quando muito, profissionais liberais.

Abdias, contudo, construiu uma importante rede de relações pessoais nos meios artísticos, acadêmicos e intelectuais do Brasil. Alguns desses homens foram de grande importância para o movimento, à medida que emprestavam seu prestígio para legitimar os pleitos dos ativistas negros, a começar pela afirmação de um "problema do negro", como fez Arthur Ramos, ou, como Thales de Azevedo, ao afirmar a discriminação racial no comércio e nos clubes sociais da Bahia, vista então como a cidade de maior integração racial do Brasil.

A necessidade de os líderes negros contestarem Pierson era tanta que não apenas acadêmicos brancos, mas quase trinta personalidades negras, profissionais liberais ou gente simples do povo foram mobilizados pela coluna de Abdias para testemunhar sobre a atualidade da discriminação racial em várias regiões do Brasil, e não apenas em São Paulo, como era voz corrente.

Seria ocioso lembrar a grande reação à mobilização política dos negros vinda do establishment conservador. O jornal O Globo, por exemplo, nunca aceitou nem mesmo a existência do TEN, visto como racismo às avessas.

Os argumentos também variavam. Alguns argüiam que a situação dos negros em São Paulo, estado de origem de grande parte dos líderes negros, não podia ser generalizada para o resto do país; outros argumentavam que a discriminação se limitava a algumas poucas instituições; havia também quem sugerisse que a natureza mestiça do povo brasileiro não permitia mobilizações raciais, enquanto outros advertiam que tal mobilização terminaria por criar quistos raciais no Brasil. Havia aqueles para quem não existia, no Brasil, um "problema do negro", mas um "problema do povo brasileiro".

Abdias do Nascimento e seus camaradas foram capazes, entretanto, de forjar no Brasil dos anos 1940 um movimento negro em aliança com artistas e intelectuais brancos, que lhes abriram as portas aos partidos políticos e à vida cultural brasileira. Estes talvez tenham tido uma enorme influência no sentido de livrar o movimento negro do pós-guerra do ranço puritano e pequeno-burguês que teve a FNB. A luta contra o preconceito racial, contudo, continuou a ser a bandeira a 
unir os negros brasileiros, e o termo "negro" foi mantido para nomear a identidade grupal, ainda que a palavra "afro-brasileiro", designando tanto a cultura quanto as pessoas, definitivamente fosse incorporada ao vocabulário da mobilização negra no Brasil. A autodeterminação política, porém, limitou-se às iniciativas culturais e educacionais e à formação do Diretório Negro do PTB.

"Democracia", significando igualdades de direitos e de oportunidades, foi, em 1946, um ideal que não se realizou. Para um país que saía de uma ditadura, em um mundo em que o fascismo acabara de ser vencido, mas em que o racismo contra os negros nos Estados Unidos tornara-se ainda mais visível, a palavra "democracia" ganhava múltiplos significados que tanto liberais quanto comunistas procuravam fixar. $\mathrm{O}$ argumento de que a democracia americana era imperfeita por causa de seu viés racial, ao contrário da emergente democracia brasileira, era uma idéia sedutora para todos, inclusive para os negros.

O protesto negro, em 1946, estava no lugar adequado e na hora certa, mas um sólido consenso nacional sobre a harmonia racial como objetivo político fazia com que a justiça racial fosse pensada como decorrente das regras democráticas. Longe de ser uma variante da supremacia branca, a democracia racial era um constructo utópico nascido da colaboração tensa entre radicais negros e progressistas brancos. No final da década, já em 1951, com a promulgação da Lei Afonso Arinos, quase todas as demandas do manifesto de 1946 tinham sido atendidas. A autonomia política dos negros, assim como o entendimento da democracia como respeito integral à cidadania e aos direitos individuais teriam, entretanto, de esperar uma nova ruptura democrática e uma nova redemocratização para se tornarem realidade. Ironicamente, para que a democracia pudesse existir, seria preciso que, antes, a "democracia racial" fosse denunciada como mito e ilusão.

(Recebido para publicação em abril de 2007)

(Versão definitiva em janeiro de 2008) 


\section{NOTAS}

1. Sobre a FNB, ver, entre outros: Fernandes (1965), Bastide (1983), Ferrara (1986), Leite (1992), Mitchell (1977), Moura (1980), Pinto (1993), Andrews (1998), Barbosa (1998), Butler (1998), Oliveira (2006).

2. Sobre o TEN, ver, entre outros, Motta-Maués (1988), Müller (1988) e Macedo (2006); sobre Abdias do Nascimento, ver Police (2000), Nascimento (2003), Semog (2006) e Macedo (2006).

3. Os ativistas eram: Francisco Lucrécio, tenente Francisco das Chagas Printes, Geraldo Campos de Oliveira, Salatiel dos Santos, José Bento Ângelo Abatayguara, Emílio Silva Araújo, Aguinaldo Oliveira Camargo, Sebastião Rodrigues Alves, Ernani Martins da Silva, Benedito Juvenal de Souza, Ruth Pinto de Souza, Luís Lobato, Nestor Borges, Manoel Vieira de Andrade, Sebastião Baptista Ramos, Benedito Custódio de Almeida, Paulo Morais, José Pompílio da Hora, René Noni, Sofia Campos Teixeira, Cilia Ambrósio, José Herbel e Walter José Cardoso (Nascimento, 1982:60-61).

4. As reivindicações aprovadas no evento político eram seis, a saber: "1- Que se torne explícita na Constituição de nosso país a referência à origem étnica do povo brasileiro, constituído das três raças fundamentais: a indígena, a negra e a branca; 2- Que se torne matéria de lei, na forma de crime de lesa-pátria, o preconceito de cor e de raça; 3- Que se torne matéria de lei penal o crime praticado nas bases do preceito acima, tanto nas empresas de caráter particular como nas sociedades civis e nas instituições de ordem pública e particular; 4- Enquanto não for tornado gratuito o ensino em todos os graus, sejam admitidos brasileiros negros com pensionistas do Estado, em todos os estabelecimentos particulares e oficiais de ensino secundário e superior do país, inclusive nos estabelecimentos militares; 5- Isenção de impostos e taxas, tanto federais como estaduais e municipais, a todos os brasileiros que desejarem se estabelecer em qualquer ramo comercial, industrial e agrícola, com capital superior a $\mathrm{Cr} \$$ 20.000.00; 6- Considerar como problema urgente a adoção de medidas governamentais visando à elevação do nível econômico, cultural e social dos brasileiros (Nascimento, 1982:59).

5. Eurico de Oliveira (1903-1998) era natural do Rio de Janeiro e filho do jornalista Domingos Alves de Oliveira. Formado em direito pela Faculdade Candido Mendes, trabalhou como jornalista em vários jornais do então Distrito Federal, como Correio da Noite, A Pátria, Jornal do Brasil, O Imparcial e A Noite, até fundar o Diário Trabalhista. Nas eleições de 1950, candidatou-se a deputado pelo Partido Trabalhista Brasileiro PTB, conseguindo apenas a suplência.

6. "Fomos encontrá-lo no quarto distrito policial, onde é comissário [...]"

7. A idéia de uma "segunda abolição", segundo Kössling, vem do integralismo e tem ressonância na FNB devido aos pontos em comum entre as duas organizações. Segundo ela: "A participação simultânea do afro-descendente na Ação Integralista Brasileira e Frente Negra Brasileira não se deve ao acaso. Partilhando de concepções sobre o Brasil e sobre a 'raça brasileira', ambas as organizações obtiveram a atenção dos afro-descendentes em São Paulo, e a comunidade entre estes parece ter sido intensa, como demonstram as notícias veiculadas pelo jornal integralista $A$ Acção, de maio de 1937, que divulgou os eventos em comemoração à Abolição realizados pela FNB, que levou palestrantes integralistas às festividades [...]". A grande preocupa- 


\section{Antonio Sérgio Alfredo Guimarães e Márcio Macedo}

ção apresentada pelos editoriais da Acção era a crítica à situação política decorrente do capitalismo. Nesse sentido, propunha uma Segunda Abolição, "elaborando uma grande força de libertação nacional, de um novo e amplo 13 de maio para o povo brasileiro [...]", pois não se observava, portanto, que o problema social vivenciado pelo afro-descendente era algo específico, decorrente de um sistema de exclusão racial que a Abolição não havia resolvido e que, muito ao contrário, gerara novas complicações (Kössling, 2004:22).

8. José Pompílio da Hora foi a principal liderança da União dos Homens de Cor no Rio de Janeiro nos anos 1950. Ver Silva (2003).

9. Está para ser estudada a influência que por acaso teve Roger Bastide, Arthur Ramos e Gilberto Freyre, entre outros, na divulgação das idéias da négritude entre os negros brasileiros. Ironides Rodrigues já manifestava alguma familiaridade com essas idéias em 1946, como vimos.

10. A idéia de que o negro no Brasil é o povo será, como sabemos, muito melhor articulada ao discurso do protesto negro por Guerreiro Ramos em sua Introdução Crítica à Sociologia Brasileira. Sobre a evolução do pensamento de Guerreiro Ramos, ver, entre outros, Oliveira (1995) e Barbosa (2004).

11. Sobre desdobramentos desse episódio, ver Andrews (1998:270-281), Bastos (1991) e Duarte (1947).

12. Hamilton Nogueira (1897-1981), médico, natural de Campos (Rio de Janeiro), fez a Faculdade de Medicina do Rio de Janeiro, turma de 1918. Recém-formado, foi trabalhar em Muzambinho (Minas Gerais), onde se tornou discípulo de Jackson de Figueiredo (1819-1928), ingressando no movimento católico denominado Apostolado. De volta ao Rio de Janeiro em 1921, ajudou a fundar o Centro Dom Vital, principal núcleo católico do Distrito Federal até a fundação da Pontifícia Universidade Católica PUC, em 1941. Entre 1921 e 1941, trabalhou no Hospital Pedro II, chegando a diretor.

13. Tal interpretação representou um passo importante para contestar a afirmação de Pierson de que o preconceito de cor era simplesmente de classe, algo de que os liberais e os socialistas ainda hoje se servem fartamente. 


\section{REFERÊNCIAS BIBLIOGRÁFICAS}

ANDRADE, Mário de. (1938), "A Superstição da Cor". Boletim Luso-Africano. Rio de Janeiro, dezembro.

ANDREWS, George Reid. (1998), Negros e Brancos em São Paulo (1888-1988). Bauru, Edusc.

BARBOSA, Márcio. (1998), Frente Negra Brasileira: Depoimentos. São Paulo, Quilombhoje/MinC.

BARBOSA, Muryatan Santana. (2004), Guerreiro Ramos e o Personalismo Negro. Dissertação de mestrado, PPGS/USP, São Paulo.

BASTIDE, Roger. (1983), “A Imprensa Negra do Estado de São Paulo". Estudos Afro-Brasileiros. São Paulo, Perspectiva.

BASTOS, Elide Rugai. (1991), “A Questão Social e a Sociologia Paulista". São Paulo em Perspectiva, vol. 5, no 1, pp. 31-39.

BUTLER, Kim. (1998), Freedoms Given, Freedoms Won: Afro-Brazilians in Post-Abolition São Paulo and Salvador. New Brunswick/New Jersey/London, Rutgers University Press.

DUARTE, Paulo. (1947), "Negros do Brasil". O Estado de S. Paulo, 16 de abril, p. 5.

FERNANDES, Florestan. (1965), A Integração do Negro na Sociedade de Classes. São Paulo, Dominus/Edusp.

FERRARA, Miriam Nicolau. (1986), A Imprensa Negra Paulista (1915-1963). Tese de doutorado, FFLCH/USP, São Paulo.

FERREIRA, Marieta de Morais. (2001), "Diário Trabalhista (verbete)", in A. A. de Abreu et alii (coords.), Dicionário Histórico-Biográfico Brasileiro Pós-1930. Rio de Janeiro, CPDoc/Editora FGV, vol. 2.

FRAZIER, Franklin. (1942), "Some Aspects for Race Relations in Brazil". Phylon-Review of Race and Culture, vol. 3, no 3 .

GAMA, Luiz. (1989), “Carta a Lúcio Mendonça, São Paulo, 25 de julho de 1880”. Novos Estudos, no 25.

GUERREIRO RAMOS, Alberto Guerreiro. (1957), Introdução Crítica à Sociologia Brasileira. Rio de Janeiro, Andes.

GUIMARÃES, Antonio Sérgio A. (2005), "Racial Democracy", in J. Souza e V. Sinder (orgs.), Imagining Brazil. Lanham, Lexington Books, pp. 119-140.

KÖSSLING, Karin Sant'Anna. (2004), “O Discurso Policial sobre o Afro-Descendente: Estigmas e Estereótipos". Revista Histórica, no 15, pp. 4-10.

LEITE, José Correia e CUTI (Luiz Silva). (1992), ... E Disse o Velho Militante José Correia Leite. São Paulo, Secretaria Municipal de Cultura.

MACEDO, Márcio. (2006), Abdias do Nascimento: A Trajetória de um Negro Revoltado (1914-1968). Dissertação de mestrado em Sociologia, FFLCH/USP, São Paulo.

MITCHELL, Michael. (1977), Racial Consciousness and the Political Attitudes and Behavior of Blacks in São Paulo. Tese de doutorado, Indiana University, Bloomington. 


\section{Antonio Sérgio Alfredo Guimarães e Márcio Macedo}

MOTTA-MAUÉS, Maria Angélica. (1988), “Entre o Branqueamento e a Negritude: O Teatro Experimental do Negro e o Debate da Questão Racial", in R. G. Müller (org.), Dionysos. MinC/Fundacen, no 28, pp. 89-101.

MOURA, Clóvis. (1980), “Organizações Negras”, in P. Singer e V. C. Brant (eds.), São Paulo: O Povo em Movimento. Petrópolis, Vozes.

MÜLLER, Ricardo Gaspar. (1988), “Identidade e Cidadania: O Teatro Experimental do Negro", in R. G. Müller (org.), Dionysos. MinC/Fundacen, no 28.

NASCIMENTO, Abdias do (org.). (1982), O Negro Revoltado. Rio de Janeiro, Nova Fronteira.

NASCIMENTO, Elisa Larkin. (2003), O Sortilégio da Cor: Identidade, Raça e Gênero no Brasil. São Paulo, Summus.

OLIVEIRA, André Côrtes de. (2006), Quem É a “Gente Negra Nacional”? Frente Negra Brasileira e A Voz da Raça (1933-1937). Dissertação de mestrado, IFCH/Unicamp, Campinas.

OLIVEIRA, Lucia Lippi. (1995), A Sociologia do Guerreiro. Rio de Janeiro, Editora da UFRJ.

PIERSON, Donald. (1942), Negroes in Brazil: A Study of Race Contact in Bahia. Chicago,University of Chicago Press.

PINTO, Luis Aguiar Costa. (1953), O Negro no Rio de Janeiro: Relações de Raças numa Sociedade em Mudança. Rio de Janeiro, Cia. Editora Nacional.

PINTO, Regina Pahim. (1993), O Movimento Negro em São Paulo: Luta e Identidade. Tese de doutorado, FFLCH/USP, São Paulo.

POLICE, Gérard. (2000), Abdias do Nascimento: L'Afro-Brésilien Reconstruit. 1914-1944 (vols. I e II). Tese de doutorado, Département de Portugais/Université Rennes 2, Haute Bretagne.

QUERINO, Manuel Raimundo. (1980), “O Colono Preto como Fator da Civilização Brasileira". Afro-Ásia, no 13, pp. 143-158.

SEMOG, Éle. (2006), Abdias Nascimento: O Griot e as Muralhas. Rio de Janeiro, Pallas.

SILVA, Josenilda. (2003), “A União dos Homens de Cor: Aspectos do Movimento Negro dos Anos 40 e 50". Estudos Afro-Asiáticos, Ano 25, no 2, pp. 215-235.

VON MARTIUS, Carl Friedrich Philipp. (1845), “Como se Deve Escrever a História do Brasil". Revista do Instituto Histórico e Geográfico. 


\section{Matérias Publicadas na Coluna "Problemas e Aspirações do Negro Brasileiro". Diário Trabalhista, Rio de Janeiro, 1946}

"Os Negros Brasileiros Lutam por suas Reivindicações", 15 de janeiro, p. 5.

“Anjos Branquinhos e Demônios Negros - Os Intelectuais Negros do Passado e os da Moderna Geração", entrevista concedida por Ironides Rodrigues, 20 de janeiro, p. 5.

“Alfabetizar é Libertar o Negro. Problemas e Aspirações do Negro Brasileiro", 23 de janeiro, p. 5 .

"Afirma o Poeta Rossine Camargo Guarnieri: Em São Paulo a Situação do Negro é Simplesmente Horrível", 25 de janeiro, p. 7.

“O Professor Joaquim Ribeiro, Invocando o Conceito do Sociólogo Sorokin, Depõe: -É Quase Nula a Mobilidade Vertical dos Negros", 27 de janeiro, p. 7.

"Pretos e Brancos Unidos, Realizarão a Construção do Brasil de Amanhã", 1 o de fevereiro, p. 7.

“O Negro e a Democracia", 3 de fevereiro, p. 7.

"A Bancada Trabalhista Dá Todo seu Apoio às Reivindicações do Negro", 8 de fevereiro, p. 5 .

“Depõe o Professor Arthur Ramos: Depois da Luta Contra Racismo, ainda Subsiste Outra, de Não Menor Gravidade: A Luta Contra a Miséria, Contra a Doença, Contra Todas as Formas de Exploração", 9 de fevereiro, p. 4 .

"A Mulher Negra Deve Tomar Parte Ativa nos Acontecimentos Políticos e Sociais do País", declaração de Arinda Serafim, 13 de fevereiro, p. 4.

“A Hedionda Injustiça Contra os Negros Está Exuberantemente Provada", 16 de fevereiro, p. 7.

“Os Negros Mais do Que Qualquer Outra Classe Social Sofrem Todos os Horrores do Capitalismo Internacional", declaração de Aguinaldo Camargo, 17 de fevereiro, p. 4. 
“É Preciso Acabar com a Exclusão Absoluta ou Relativa nas Guardas Palacianas, nas Escolas para o Oficialato das Forças Armadas e Mesmo na Diplomacia", 28 de fevereiro, p. 7.

"Antiisolacionismo Negro por Abdias do Nascimento", 9 de março, p. 6.

“Aqui, Nesta Terra de Negros, Mulatos e Creoulos, Onde as Raças se Fundem em um Só Bloco, Existe uma Luta Surda Contra e Passiva Contra a Gente de Cor, Só por Ser de Cor", 12 de março, p. 6.

"O Preconceito de Cor Está aí, Lanhando as Carnes do Negro para Quem Quiser Ver", 17 de março, p. 6.

“Será Preciso que os Racistas Indígenas Passem por um Processo de Reeducação Semelhante ao que as Nações Unidas Estão Levando a Efeito na Alemanha e no Japão", 21 de março, p. 6.

"O Senador Hamilton Nogueira Denunciou a Constituinte uma Fraude Contra o Negro", 24 de março, p. 6.

"As Mulheres Negras Também Reivindicam seus Direitos", 5 de abril, p. 5 .

"A Discriminação é Fato Infelizmente Verdadeiro no Brasil", 10 de abril, p. 4.

“Manifesto da Convenção Nacional do Negro Brasileiro. Os Pretos Não Estão Criando Nenhum Problema, Declarou o Senador Hamilton Nogueira nos Debates Públicos sobre a Questão Negra", 30 de abril, p. 5.

“O Mais Belo Povo Mestiço do Mundo", 16 de maio, p. 5.

"O Desaparecimento do Preconceito de Cor Não Pode Ser Fruto de Cambalacho Político-Partidário", 18 de julho, p. 4.

"A Questão do Negro no Brasil Não É Caso para Partidos", 1ํ de agosto, pp. 6-8.

“Creio na Valorização do Trabalhador", 16 de agosto, p. 3.

"O Teatro Experimental do Negro e a Cultura do Povo", 15 de agosto, p. 4.

“O Movimento Progressista do Brasil Estaria Incompleto se lhe Faltasse a Cor do Movimento Afro-Brasileiro", 8 de setembro, p. 6. 
Diário Trabalhista e Democracia Racial Negra dos Anos 1940

"O Negro em Marcha", 12 de outubro, p. 5.

"Em Defesa dos Afro-Brasileiros", 28 de novembro, p. 5. 


\section{ABSTRACT}

Diário Trabalhista and Black Racial Democracy in Brazil in the 1940s

In order to refute the interpretation that racial democracy in Brazil has simply been an illusion or ruse of white supremacy, the authors analyze the participation of Black leaders in the elaboration of the Brazilian national imaginary in the 1940s. They argue that during that period, racial democracy was a powerful instrument for mobilizing Blacks as well, whether as nationalists or anti-racists. The authors explore one of the most important sources through which this ideology was forged by a key figure of the Black intelligentsia, Abdias do Nascimento, with his column in the Diário Trabalhista [Laborite Daily] entitled "Problems and Aspirations of Black Brazilians". In this column, Nascimento published dozens of interviews with Black leaders and common people that demonstrate the foundations, principles, and interests involved in the construction of a racial democracy.

Key words: racial democracy; Abdias do Nascimento; blacks

\section{RÉSUMÉ}

Diário Trabalhista et la Démocratie Raciale Noire des Années 1940

Afin de repousser l'interprétation selon laquelle la démocratie raciale au Brésil n'a été qu'une illusion ou une manoeuvre de la suprématie blanche, dans cet article on étudie la participation active de leaders noirs pour la formation de l'imaginaire social des années 1940. On y affirme que, pendant cette période, la démocratie raciale a été aussi un puissant instrument de mobilisation des Noirs, soit en tant que nationalistes, soit en tant qu'anti-racistes. L'une des plus importantes sources où une telle idéologie s'est formée revient à Abdias do Nascimento, personnage-clé de l'intelligentsia noire. Au Diário Trabalhista, Abdias, dans sa colonne habituelle intitulée "Problèmes et aspirations du noir brésilien", a publié dizaines d'entretiens avec des dirigeants noirs et des gens très simples, révélant les fondements, les principes et les intérêts nécessaires à la construction d'une démocratie raciale.

Mots-clé: démocratie raciale; Abdias do Nascimento; Noirs 